\title{
Embryonic Stem Cells: Introducing Exogenous Regulators into Embryonic Stem Cells
}

\author{
Yong-Pil Cheon \\ Sungshin Women's University, Dongseondong 3ga, Seoul, \\ Korea
}

\section{Introduction}

The application of embryonic stem (ES) cells to research and therapy has been a landmark development in science. Cell therapy using ES cells depends on the progress of the stable culture conditions and differentiation induction methods. ES cells were first obtained directly from inner cell masses (ICMs) of blastocysts by Evans and Kaufman (1981), and Martin (1981). These cells can self renew to produce stem cell itself and repopulate into many different tissues, including the somatic- and germ-cell lineages in chimeras (Bradley et al., 1984). After developing the methods for establishing the ES (mES) cell lines of mice, ES cell lines of other species including primates and human were also established (Thomson et al., 1995, 1998). Although ES cells can be obtained from 8-cell stage embryos or morula, they are more easily obtained from blastocyst stage embryos (Delhaise et al., 1996; Strelchenko et al., 2004). Now the sources of ES cells have been extended to include epiblast cells (Nichols and Smith, 2011) (Fig. 1).

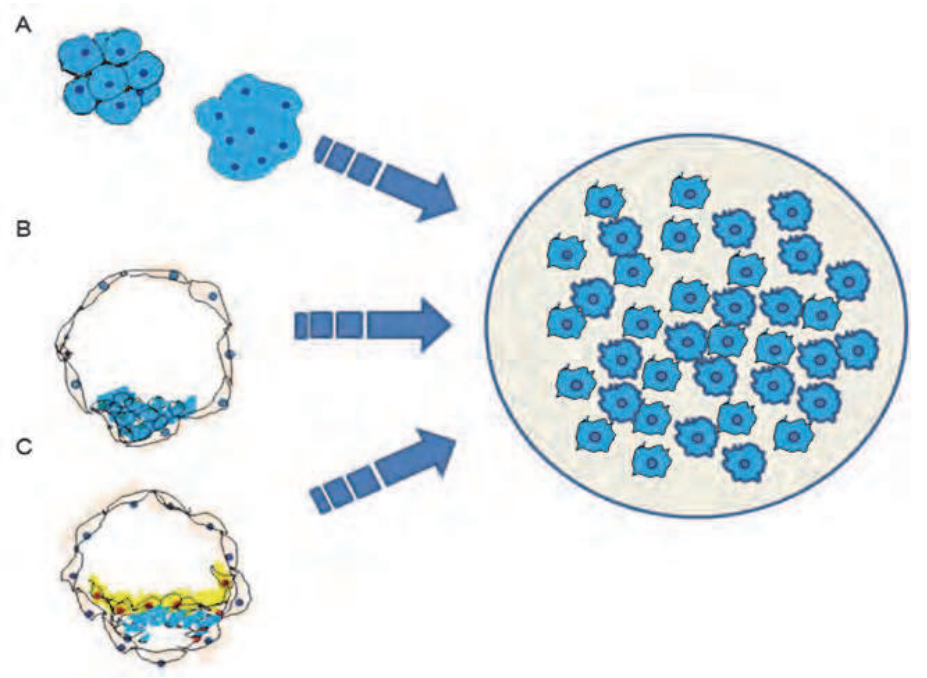

Fig. 1. The origins of embryonic stem cell. A, blastomeres of 8-cell and morula stage embryos; B, inner cell mass of blastocyst; C, epiblast cells of implanting embryo. 


\section{Human and mouse embryonic stem cells}

\subsection{Mouse embryonic stem cell}

mES cells have been used mainly in the generation of mutant mice and in investigating cellular differentiation and the physiological role of genes during embryogenesis and development. These things can be accomplished through gene targeting and transmission of the acquired characters. Transmission of foreign genes to the next generation can be accomplished with incorporation of foreign genes into the germ cell-lineage (Bradley et al., 1984; Wang et al., 1996). Specific gene deficient mice can be developed by manipulation of the genes in ES cells and introduce of ES cells into ICM (Hooper et al., 1987; Kuehn et al., 1987; Wang et al., 1996). Mutations targeting specific genes by homologous recombination in ES cells have been designed and initially achieved using hypoxanthine-guanine phosphoribosyl transferase (HPRT) (Doetschmann et al., 1987). Germ line transmission of a targeted mutation in a gene other than HPRT was first obtained with c-abl (Schwartzberg et al., 1989) and $\beta 2$-microglobulin (Zijlstra et al., 1989). To date, several hundred genes have been disrupted by homologous recombination in ES cells. The application of these techniques provided a way to evaluate the physiological roles of specific genes in ontogeny. In addition, conditional knockout mice are developed using ES cells and are used to analyze gene functions in a specific tissue or developmental stage. These approaches have provided much novel information and several important tools to study human development including ES cell therapies.

\subsection{Early data from embryonic carcinoma cells}

Human ES (hES) cells have become a key word in basic sciences and applied sciences. Before the optimal conditions were established for ES cell cultures, most of the basic knowledge about ES cells came from studies on embryonic carcinoma (EC) cells (Jakob, 1984; Rossant and Papaioannou, 1984; Smolich and Papkoff, 1994). The first human EC cell line was established in vitro in 1985 (Sekiya et al., 1985). EC cells can spontaneously differentiate into somatic cells, germ cells and extraembryonic cells (Zákány et al. 1984), and have self-renewal ability (Andrews, 1987; Rosenstraus et al., 1984). During differentiation of EC cells into other cell types, proliferation is prerequisite, and apoptosis of EC cell derivatives accompany this process (Azizi et al., 2010; Mummery et al., 1984). After starting differentiation, the expression levels of some genes are determined at the levels of transcription and translation. In 1984, Schindler and Sherman reported the profile of protein and mRNA expression in murine EC cells, and the expression patterns of specific genes were explored during differentiation of EC cells (Scott et al., 1984; Silvan et al., 2009). Additionally, studies on proteins and carbohydrates have been performed to characterize the EC cells and their induced descendants (Amano et al., 2010; Andrews et al., 1984; Jemmerson et al., 1985). The role of the extracellular matrix is also examined during differentiation induction of EC cells (Grabel, 1984; Wartiiovaara et al., 1984) as the karyoplasm in EC cell gene expression (Gautsch, 1982). Differentiation induction of EC cells has been successful with various substances, such as retinoic acid, dibutyryl cyclic AMP (Jones-Villeneuve et al., 1983; Muramatsu and Muramatsu, 1983), dimethyl sulfoxide (Edwards et al., 1983) and coculture with specific cell types (Allin, 1984). Bell et al (1984) used growth factors to induce EC cell differentiation in target tissues. 


\subsection{Stemness and the differentiation of embryonic stem cells}

Although ES cells share some characteristics with EC cells, they have important differences (Chamber and Smith, 2004). The in vitro developmental potency and differentiation of ES cells have been studied since the mid-1980s. The developmental potency of ES cells was studied in vitro by Doetschman et al (1985). Additionally, the pluripotency and the characteristics of ES cells in vitro were analyzed in depth. ES cells lack differentiationinhibitory activity (DIA) unlike cells of cell lines, and they can differentiate into a wide variety of cell types. ES cells have an apparently normal diploid karyotype during long-term culture, can extensively colonize embryos without causing tumors or developmental anomalies, and can form normal gametes when differentiated into the germ line (Kaufman et al., 1983; Martin, 1981; Suda et al., 1987). The purified and cloned myeloid leukemia inhibitory factor (LIF) can exhibit DIA in the maintenance of competent mES cell lines (Smith et al., 1988; Williams et al., 1988). However, the requirement for maintaining stemness varies with the source of the ES cells. Primate ES cells stay in an undifferentiated state when grown on embryonic fibroblast feeder layers but differentiate or die in the absence of feeder cells, despite the presence of recombinant leukemia inhibitory factor (Thomson et al., 1995).

Studies on the differentiation of stem cells during organogenesis have a long history (Ruch, 1967). ES cell differentiation in vitro is controlled by exogenous factors, particularly paracrine factors (Heath and Smith, 1986; Spence et al., 2010). Various cell types can be induced from embryoid bodies using paracrine factors (Risau et al., 1988). During differentiation induction, various genes, such as genes of transcription factors, are upregulated or down-regulated (Dyson et al., 1989). The up-regulated transcription factors trigger a series of gene expression changes for the formation of a specific cell type (Kopp et al., 2008).

\section{Potency of embryonic stem cell in clinic}

\subsection{Sources of human embryonic stem cells}

Through the accumulating knowledge on pluripotency and on the control of cellular differentiation, a fundamental understanding of developmental biology at the cellular and molecular levels has been expanded. It represents a gateway to major future clinical applications of these principles. The levels of transcription factors including nuclear receptors in ES cells are critical in the maintenance of stemness or differentiation of ES cells (Jeong and Mangelsdorf, 2009; Redshaw and Strain, 2010). Certain nuclear receptors are involved in the maintenance of ES cells in cooperation with Oct3/4, Nanog and Klf4 upon exogenous signals. Liver receptor homolog 1 (LRH1) and estrogen-related receptor beta (ERR $\beta$ ) have functional roles in the maintenance of stemness of ES cells. On the other hand, germ cell nuclear factor (GCNF) and retinoic acid receptors (RARs) promote ES cell differentiation (Jeong and Mangelsdorf, 2009). The Sall gene family that encodes a group of developmental transcription factors controls the embryonic development and is also involved in the determination of ES cell fate. Sall1 knockout mice die perinatally with kidney dysgenesis or agenesis. Sall3 knockout mice have plate deficiency and abnormalities in cranial nerves. Sall4 mutation causes Acro-renal-ocular syndrome and Duane-radial ray syndrome. Sall4 also plays a role in the maintenance of stemness of ES cells through controlling its own expression and the expression of OCT4 (Yang et al., 2010). Identifying such switching molecules that regulate ES cell self-renewal versus differentiation can 
provide insights into the nature of the ES cell (Navarro et al., 2010). Chromatin methylation is one example of how an epigenetic modification can modulate ES cell fate (Christophersen and Helin, 2010).

In the late of 1990s the possibility of using ES cells for medicine was suggested (Gearhart, 1998). The use of stem cells in regenerative medicine already has a long history, for example, in bone marrow transplantation and skin grafting. With the establishment of human embryonic stem (hES) cell lines, future clinical applications based on their developmental and regenerative abilities will become possible. hES cells were first established in 1998 by Thomson and colleagues. As in primate ES cells, the feeder layer seems essential for maintaining the hES cell lines. It is suggested that TGF-beta and myofibroblasts can support the propagation of hES cells in vitro (Kumar et al., 2010).

Previously, the source of hES cells was restricted to morula and blastocysts but this is no longer the case. In 2006, induced pluripotent stem (iPS) cells were generated from mouse embryonic or adult fibroblasts by the retrovirus-mediated introduction of four transcription factors, Oct3/4, sox2, c-Myc, and Klf4 (Takahashi and Yamanaka, 2006). In 2007, iPS cells were established from human fibroblasts via introduction by the same four factors (Takahashi et al., 2007), and by using a slightly different combination of genes (Yu et al., 2007). Human iPS cells are similar to human ES cells in many aspects, e.g., morphology and proliferation ability. Furthermore, mouse iPS cells are competent for adult chimeric mice and germline transmission. Growth potential, gene expression patterns, and the epigenetic status of iPS cells are similar to those observed in hES cells. iPS cells can differentiate into all three germ layers through embryoid bodies and to teratomas. In addition, they have been differentiated directly into neurons, beating cardiomyocytes in vitro (Carvajal-Vergara et al., 2010) and others (Liu et al., 2011).

\subsection{Applied developmental biology}

A fertilized mammalian oocyte is totipotent and develops into the fetus and placenta concurrently losing its totipotency. During cleavage, the transition from maternal to embryonic genome activation encompassed in early stage embryos and cleaving embryos can gain the competence to become blastocysts (Hamatani et al., 2004). The competency to accomplish implantation and further development is gained during the periimplantation stages. For that process, the epithelium like structure, trophectoderm is formed and interacts with the epithelium of the uterine endometrium. On the other hand, the cells isolated within the blastoceol become inner cell mass (ICM) (Johnson and Mcconnell, 2004). ICM is a mass of cells having pluripotency and its cells can differentiate into all cell types of adult and extraembryonic membranes (Fernanez-Tresquerres et al., 2010). In specific in vitro conditions, ICM cells can keep their potency and maintain their proliferation ability (Yamanakaet al., 2006).

Grouped cell movement and sequential spatio-temporal expressions of gene sets was observed after implantation. As a consequence of gastrulation, the embryos have three germ layers, endoderm, mesoderm and ectoderm (Hassoun et al., 2010; Luxardi et al., 2010). This process is accomplished with the forming of the axis (Rocha et al., 2010). For example, Med12, a large protein complex of 30 subunits interacting with transcription factors, is essential in correct Wnt/ $\beta$-catenin and Wnt/ planar cell polarity signaling (Rocha et al., 2010; Taatjes et al., 2004).

Most cells of embryos are eventually committed through triggering to a particular developmental pathway from which they rarely depart (Belting et al., 2004). Cell 
determination is a stepwise process, and that full determination is preceded by a state of bias. This bias is either conformed or modified through cell interactions later in development. It is accomplished through community effect, lateral inhibition among equivalent cells, and embryonic induction which is the interaction between nonequivalent cells (Artavanis-Tsakonas et al., 1999). The determined state is almost stably passed on during mitosis. These are matched with the default progression and/or induced progression.

A specific type cell is derived from a preexisting progenitor or stem cell for the specific area (Belting et al., 2004; Frieberg, 1996). Designed modification of a group of ES cells to a specific cell type is mostly achieved by step by step induction through morphogens or intracellular signaling molecules as shown during organogenesis (Osakada and Takahashi, 2011). The accumulation of knowledge regarding tissue genesis and organogenesis during gastrulation will give rise to the accomplishment of goals across other fields.

The revolutionary advances in developmental biology have extended the utility of ES cells to both therapy and industry. As applied to the study of developmental biology (Lehtonen et al., 1989), the stemness and developmental potency of ES cells can be applied to various fields of medicine (Gearhart, 1998; Saxena et al., 2010). Thus far, stem cell biology has focused on identifying novel pathways such as those that maintain pluripotency and induce specific cell types. However, to date, it is not yet feasible to use ES cells in medicine or to strictly control their differentiation to a specific cell type in humans. To readily apply ES cells in therapy or other industries, the improvement of efficient protocols to direct stem cell differentiation into well-defined lineages is critical (Heng et al., 2004).

\section{Approaches to modulate embryonic stem cell properties}

To obtain a specific cell type, it is critical to understand the interactions of multiple genes and the associated factors that are involved in the differentiation and de-differentiation of ES cells. When we use inducers to generate a specific cell type from the embryoid body (EB) or directly from ES cells, it is difficult to generate single cell types at one time (Lu et al., 2009; Park and Lee, 2007). As shown in gastrulation and organogenesis, most morphogens and inducers are secreted into the intercellular fluid and into induced concentration-dependent specific gene expressions in neighboring cells (Wolpert, 1978). Therefore, in most cases of induction by inducer, unexpected results can occur during the induction of a cell type from an ES cell or embryoid bodies (EBs).

Selective activation of the gene sets is essential to get a unique function of a specific cell. One of the best ways to accomplish this is through the delivery of a construct which contains target genes and expression-control sequences (Ishizaka et al., 2002). Among them intracellular signaling mediators and transcription factors are key molecules to get a specific cell type and they are main target for differentiation induction. To meet these requirements, many experimental conditions and gene delivery systems have been used. However, ES cells cannot be translocated to high affinity variable regulators such as a molecule of DNA, RNA or proteins. To overcome this problem, various approaches have been developed. When we classified according to their characteristics, mediators are either chemical, physical, or viral.

Induced pluripotent stem cell (iPS) is a good example of a cell type in which transgene delivery and induction by transcription factors has been successful (Meissner et al., 2007; Park et al., 2008). However, those strategies introduce changes in DNA sequences or 
disorder in genomic equivalence. Moreover, viral systems are suspected to have lifethreatening effects of immunogenicity and carcinogenicity. In addition, the efficiency of gene transfer in hES cells is still poor compared with other cell lines (Cao et al., 2010; Wasungu and Hoekstra, 2006).

For these reasons, many scientists hesitate to use these strategies in medicine and have searched for new ways to control ES cell differentiation. Functional protein is easily turned over in the cytoplasm and regulates the function of a cell without disturbing the genetic background. Therefore, if we develop an easy way of introducing the transcription factors, intracellular signaling molecules or drug molecules into ES cells, ES cells will become a safe medicine.

\subsection{Delivery of nucleotides in to ES cells}

Introduction of regulating DNA or RNA into ES cells can be mediated by chemicals. Leaped progress in chemical mediated method has led to successful expression-construct delivery. Chemical mediators include diethylaminoethyl-dextran (DEAE-D), calcium phosphate, cationic lipid (liposome), cationic polymer, polylysine, histone, chitosan and peptides.

The delivery of DNA or RNA with calcium phosphate was developed by Graham and van der $\mathrm{Eb}$ (1973) and has become a common method (Marucci et al., 2011). The mixture of DNA construct, calcium ion and phosphate are presented to cells in culture and the cells import the mixture through endocytosis. DEAE-D was developed by Pagano and Vaheri in 1965 for enhancing the infectivity of poliovirus RNA for cell culture. DEAE-D is a polycation, and the mixture of DNA and DEAE-D is positively charged. It is known that the mixtures are transferred into cytoplasm through endocytosis. Cationic lipids for DNA-transfection procedures were developed in 1987 (Felgner et al., 1987) and have become one of the most common methods (Templeton et al., 1997). Cationic lipids form liposome and the surface of liposome is positively charged. Cationic polymers are a group of highly water-soluble molecules such as polyethyleneimine (PEI) and dendrimers (Boussif et al., 1995; Dunlap et al., 1997). There are several types of cationic polymers; linear (polylysine, spermine, and histone), branched (polyethyleneimine, dendrimers) and spherical (Chitosan) (Zhao et al., 2006). Cationic polymer self-assemble with DNA and generate tortoidal or spherical particles (Tang and Szoka, 1997). Polyplexes are engulfed by cells. Cationic peptide carriers are a new development and are expected to have an important role in gene delivery in vivo and in vitro. The peptides bind with DNA through ionic interaction to the phosphate backbone and additional noncovalent bonds. The transport mechanisms are endosomolytic (Chen et al., 2001) or membrane-penetrating (Xia et al., 2001). This method is not commonly used to carry the DNA or RNA constructs but the modular design of proteins is a good method for gene delivery (Xavier et al., 2009).

Among the chemical mediated methods, mostly cationic lipids are employed in ES cells (Liou et al., 2010; Ma et al., 2004). One of the merits of the cationic lipid methods is that it is simple to apply. Methods which are optimized to ES cells or EB are a developing field (Liou et al., 2010; Ma et al., 2004; Villa-Diaz et al., 2010). In the case of the other chemical mediators, the efficiency is quite low or inadaptable to ES cells (Hong et al., 2004). On the other hand, combined methods are developed in ES cells such as peptide-liposome (Torchilin et al., 2003)

On the other hand, physical forces such as, pressure, sound, shock, wave, or electrical pulse are used to deliver constructs. The history of using physical methods for gene delivery is 
relatively short. The good points of these methods are saving cost, reducing risk through the large amount of DNA, and standardizing the quantity and procedure of gene delivery. The restriction of physical delivery includes restriction of delivery into the nucleus and internal organs or tissues that are difficult to reach. The microinjection method is one widely used procedure to delivery DNA or RNA constructs directly into the cells. Using injection pipette the constructs are introduced into the cytosol or microorganells of the target cell and it makes it possible to study the complicated cellular processes, structure, and function. Usually direct DNA inoculation by conventional needle injection and hydrodynamics deliver the naked plasmid DNA into cells, tissues or organs in vivo. These are very restricted, so far (Davis et al., 1993; Zhang et al., 1999). The genetic shotgun was introduced for gene delivery in 1990 (Armaleo et al., 1990). In this protocol, microscopic tungsten spheres are used to deliver DNA or RNA constructs. This method has been used to transfect plants cells, muscle cells, and various cultured cells including epithelial cells, endothelial cells, and monocytes (Chou et al., 2004). Gene delivery using electroporation is the most versatile method and can be applied to a wide variety of cell types. A short-pulsed electric field can result in the cellular uptake of DNA. Ultrasound is another physical energy source to open the membrane. Using this energy, new gene delivery methods have been developed. It facilitates the transfer of DNA into cells and across tissues. Its efficiency is very high and intraturmoral injection of DNA followed by focused ultrasound increased the expression of the target gene (Watanabe et al., 2010). The polymer-encapsulated microsphere delivery system developed the DNA construct in a manner of controlled drug-delivery. It can deliver the constructs in a manner that has site-specificity, is nuclease-safe, and provides a sustained release of DNA without repeated administration (Little et al., 2004). Polymer-encapsulated microsphere delivery may be useful in therapy in vivo (Little et al., 2004).

Among the physical force mediated transduction methods, electroporation has been used as a standard transfection method for mES cells because its efficiency is quite high (Ma et al., 2004). However, its use has also been limited because the viability of the transfected cells is quite low (Matsuoka et al., 2007; Svingen et al., 2009). The other limit is that ES cells have to located in a spedific chamber to get treatment. However, with the progression of the electroporation system, it is possible to get a large fraction of transiently transfected cells with minimal loss of cell viability and pluripotency (Moore et al., 2010). The microinjection method, conventional needle injection, hydrodynamics deliver, genetic shotgun, ultrasound and polymer-encapsulated microsphere delivery systems are not yet commonplace and, although further research is needed, it is expected that physical mediators will be good tools for working with ES cells.

Virus mediate foreign gene delivery is observed in nature. Viruses have host specificity and the efficiency of viral infection can be increased by higher titers while avoiding immunosurveillance by an infected host. Using those characteristics, viral genomes have been developed as gene-delivery vehicles, since the early 1980s (Berkner, 1988; Shimotohno and Temin, 1981). Viral vectors include the adenoviruses, adeno-associated viruses, herpes simplex viruses, baculoviruses, lentiviruses, retroviruses and alphaviruses (Robbins and Ghivizzani, 1998; Couto and High 2010). The characteristics of vectors are dependent on their origins. Varial mediated gene delivery is a powerful method used with ES cells. iPS cells are a good example of viral mediate gene delivery of functional DNA constructs (Meissner et al., 2007; Park et al., 2008). 


\subsection{Delivery of functional proteins}

DNA constructs are powerful mediators for induction of ES cell differentiation. However, genetic modification by exogenous DNA construct can cause unidentified side effects. The development of a safe and efficient differentiation controller is, therefore, an urgent requirement for the effective implementation of stem cells in therapy and industry. As an efficient differentiation controller, functional proteins such as signal transduction proteins and transcription factors are suggested, because they degrade rapidly in physiological condition and can maintain or modulate the cell types.

The molecular size of the protein is huge compared with the amino acid and cannot freely pass the cell membrane or nuclear membrane. To deliver proteins, cationic lipids and cationic polymers also have been applied (Murthy et al., 2003; Verdurmen and Brock, 2011). However, their translocation efficiency is variable, depending on the cell type and the size and quality of the mixtures. Besides, the functional proteins cannot be translocated into the karyoplasms. Peptides are also a useful candidate for the translocation of peptides into cytoplasm but it also has limitations in medical or biological application. However, they have aroused great interest and have continuously progressed.

Cell-penetrating peptides (CPPs) are synthesized peptides derived from various proteins. CPPs can transport small molecules, peptides and proteins in the form of recombinants and mixtures (Sawant and Torchilin, 2010). Some transcription factors have a domain with strongly basic heteropeptides, containing at least four arginines and lysines, which functions as a nuclear localization signal (Boulikas, 1994; Henkel et al., 1992). Drosophila transcription factor Antennapedia (Antp) also has the ability to translocate across the cell membranes (Balayssac et al., 2006). A mildly hydrophobic segment located approximately 30 residues downstream of the signal peptide is critical in membrane permeability in an E. coli protein (Nilsson et al., 1993). Those sequences interacting with lipid bilayers are called CPPs. They can carry functional cargo in the form of transcription factors or drugs (Lin et al., 1995). CPPs are also referred to as cell-permeable peptides, protein transducing domains (PTDs), or Trojan horse peptides. Thus far, the designed CPPs are more than two hundred including a galparan analog (Pooga et al., 1998), poly-arginine (Wadia and Dowdy, 2003), TAT-PTD, penetratin, buforin 2, transportan, transportan 10, MAP, pVec, R8, R11, KALA, K-FGF, PEP1, and Synb1 (Chugh et al., 2010; Dietz and Bähr, 2005; Pooga and Langel, 2005) (Table 1). CPPs are able to ferry much larger proteins, chemicals, DNA or RNA, directly into living cells (Dietz, 2010; Jung et al., 2007; Kwon et al., 2009).

Applying CPPs to basic sciences, medicine and industry has been attempted. CPPs can translocate a specific protein into the cytoplasm in mixed form or recombinant protein form. Using a recombinant cell-permeable Cre protein (His-TAT-NLS-Cre), recombination can be efficiently induced in mES cell-derived cells. Fortunately, the permeable Cre protein has no overt side effects on proliferation and neural differentiation (Haupt et al., 2007). Yang and colleagues (2009) worked with a library of poly-(beta-amino ester) end-modified derivatives. These derivatives were developed and optimized for high transfer efficiency in hES cellderived cells, human adipose-derived stem cells (hADSCs) and human mesenchymal stem cells (hMSCs). In the presence of $10 \%$ serum, the transfer efficiency was $27 \pm 2 \%$ in hMSCs, $24 \pm 3 \%$ in hADSCs and $56 \pm 11 \%$ in hSECds (Yang et al., 2009). Recently human iPS cells were successfully established with CPP-conjugated reprogramming proteins (Kim et al., 2009). However, the importation efficiency was poor. 


\begin{tabular}{|c|c|c|c|c|}
\hline \multirow{2}{*}{ СРP } & \multirow{2}{*}{ Cys-CPP Sequence } & \multicolumn{2}{|c|}{ Numer of } & \multirow{2}{*}{ Class of CPP } \\
\hline & & Lys & Arg & \\
\hline Tat-PTD & GRKKRRQRRRPPQ & 2 & 6 & Cationic \\
\hline Penetratin (ATF) & RQIKIWFQNRRMKWKK & 4 & 3 & Cationic \\
\hline M918 & MVTVLFRRLRIRRASGPPRVRV & 0 & 7 & Cationic \\
\hline KALA & $\begin{array}{l}\text { WEAKLAKALAKALAKHLAKAL } \\
\text { AKALKACEA }\end{array}$ & 7 & 0 & Cationic \\
\hline R7 & RRRRRRR & 0 & 7 & Cationic \\
\hline R8 & RRRRRRRR & 0 & 8 & Cationic \\
\hline R11 & RRRRRRRRRRR & 0 & 11 & Cationic \\
\hline MAP & KLALKLALKALKAALKLA & 5 & 0 & Amphipathic \\
\hline pEP-1 & KETWWETWWTEWSQPKKKRKV & 5 & 1 & Amphipathic \\
\hline Buforin 2 & TRSSRAGLQFPVGRVHRLLRK & 1 & 5 & Amphipathic \\
\hline Transportan 10 (P10) & AGYLLGKINLKALAALAKKIL & 4 & 0 & Chimeric \\
\hline Transportan & $\begin{array}{c}\text { GWTLNSAGYLLGK'bINLKALAAL } \\
\text { AKKIL }\end{array}$ & 4 & 0 & Chimeric \\
\hline $\mathrm{pVec}$ & LLIILRRRIRKQAHAHSK & 2 & 4 & Chimeric \\
\hline K-FGF & AAVALLPAVLLALLAP & 0 & 0 & $\begin{array}{l}\text { Hydrophobi } \\
\text { c sequences }\end{array}$ \\
\hline$\beta 3-S$ & AAVALLPAVLLALLAP & 0 & 0 & $\begin{array}{l}\text { Hydrophobi } \\
\text { c sequences }\end{array}$ \\
\hline SynB1 & RGGRLSYSRRRFSTSTGR & 0 & 6 & $\begin{array}{l}\text { Antimicrobia } \\
1 \text { sequence }\end{array}$ \\
\hline NLS & ALWKTLLKKVLKAPKKKRKVC & 8 & 1 & $\begin{array}{l}\text { Antimicrobia } \\
1 \text { sequence }\end{array}$ \\
\hline
\end{tabular}

b: attachment of Cys(Npys) on the

Table 1. Sequences and features of some cell-penetrating peptides

To promote the transduction of functional proteins into cytoplasm and karyoplasms of ES cells, the transduction abilities of various types of CPPs have been analyzed in mES cells (Jung et al., 2007). In these studies, the effects of the site of the CPP and the His tag in functional recombinant protein were first analyzed. We chose two expression vectors, one with an N-terminal His tag (6xHis-tag) and the other with a C-terminal tag (Fig. 2). Buforin 2 cannot mediate the translocation of conjugated EGFP into the cytoplasm of R1 mES cells whether the His tag is located N-terminally (Buforin 2-EGFP-N) or C-terminally (Buforin 2EGFP-C). In contrast, pEP-1-EGFP-N translocates into the cytoplasm of R1 ES cells but pEP1-EGFP-C does not. pEP-1-EGFP-C mainly localized at the plasma membrane. The translocational efficiency of a CPP depends on the amino acid sequence and the length of the CPP. Buforin 2 is a 21-residue peptide containing a +7 net charge (TRSSRAGLQFPVGRVHRLLRK) and is a membrane-permeabilizing antimicrobial peptide (Takeshima et al., 2003). Its structure is amphipathic, consisting of an N-terminal random coil region, an extended helical region, a hinge, and a C-terminal regular $\alpha$-helical region. The membrane permeability is dependent on the $\alpha$-helical content of the peptides (Park et al., 2000). Although it efficiently translocates into HeLa cells (Takeshima et al., 2003), it cannot penetrate ES cells whether the 6xHis-tag is located N-terminally or C-terminally (Fig. 3). 
In HeLa cells, buforin 2-mediated translocation of proteins is concentration-dependent but temperature-independent (Takeshima et al., 2003). pEP-1 is a 21-residue peptide with a +6 net charge (KETWWETWWTEWSQPLKKRKV), and is a membrane-permeabilizing antimicrobial peptide and is amphipathic. pEP-1 can be translocated into cytoplasm and karyoplasms of R1 mES cells when the 6x His is located N-terminally (pEP-1-EGFP-N), as in COS-7 cells (Petrescu et al., 2009), but pEP-1-EGFP-C cannot penetrate the R1 cell membrane (Fig. 3) (Jung et al., 2007). The translocation of Buforin 2-EGFP-N, Buforin 2-EGFP-C, pEP-1EGF-N and pEP-1-EGF-C does not depend on their concentrations (Fig. 4) (Jung et al., 2007). Translocation into the cell by pEP-1 dose not depend on energy (Henriques et al., 2007). It is suggested that electrostatic interactions are most important in the pEP-1 membrane interactions (Henriques et al., 2007). Although both Buforin 2 and pEP-1 are amphipathic, their translocation effects in ES cells differ. Additionally, the penetration affinity of pEP-1 is changed by the 6xHis-tag. Based on these observations, it is suggested that the $\mathrm{N}$-terminal location of His on pEP-1 is responsible for its cell-penetrating efficiency. Therefore, the penetration effects of CPPs in ES cells are different from other cell types, such as epithelialderived cell lines or stroma-derived cell lines (Jung et al., 2007; Petrescu et al., 2009; Takeshima et al., 2003).

Although 6xHis-tag is important in the efficiency of pEP-1 penetration into ES cells, the best strategy to express functional proteins in cells is to use a vector with a C-terminal tag. Based on the previous analysis, R7, MAP, pVec, K-FGF and yPFY were chosen as CPP and analyzed for their ability to transport EGFP through the plasma membrane of ES cells. R7 is an arginine-rich peptide with a +7 net charge. $p V e c$ is an 18-amino-acid peptide with a +8 net charge and is derived from the murine vascular endothelial-cadherin protein (Elmquist et al. 2010; Hällbrink et al., 2001). N-terminal hydrophobic part of pVEC is crucial for efficient cellular translocation (Elmquist et al., 2006). MAP (KLAL, model amphipathic

\section{EGFP}

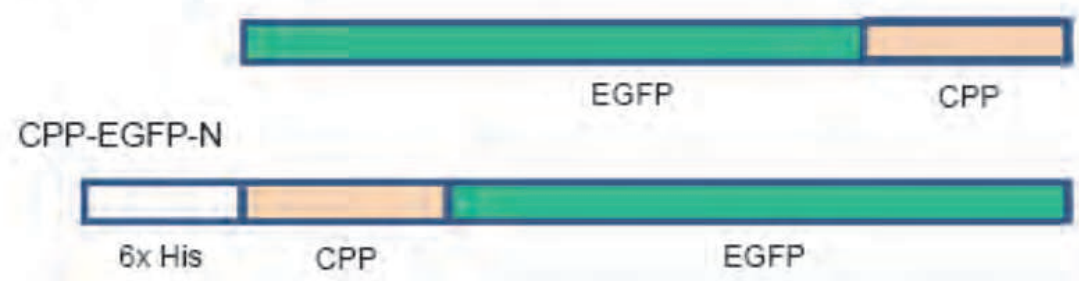

CPP-EGFP-C

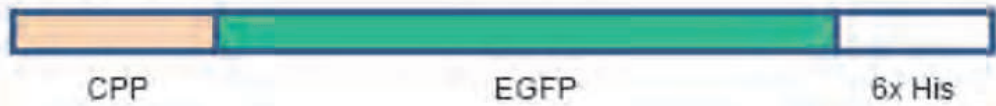

Fig. 2. Constructs of recombinant EGFP, CPP-EGFP-N and Pep-1-EGFP-C. In this construct, we wanted to use $6 x$ His-tag for purify and identification. Because it is known that 6 xHis-tag usually do not disturb the formation of 3-dimensional structure and function of gene products. It is possible that His has + charge and it can effect on the role of CPP. Therefore we tested the possible effects of $6 x$ His on the ability of CPPs. 



Fig. 3. Translocation of EGFP-N and -C ( $\mathrm{A}_{-1}$ and $\mathrm{A}_{-2}$, respectively), Buforin 2-EGFP-N and -C ( $\mathrm{B}_{-1}$ and $\mathrm{B}_{-2}$, respectively), and pEP-1-EGFP-N and $-\mathrm{C}\left(\mathrm{C}_{-1}\right.$ and $\mathrm{C}_{-2}$, respectively) into R1 mES cells $24 \mathrm{hr}$ after treatment. In natural culture condition, EGFP could not pass the cell membrane and the R1 ES cell did not take it through endocytosis. Site of 6xHis-tad did not give effect on the Buforin-2 transduction ability in mES cells but it gave effect on the pEP-1 transduction ability in mES cells. 


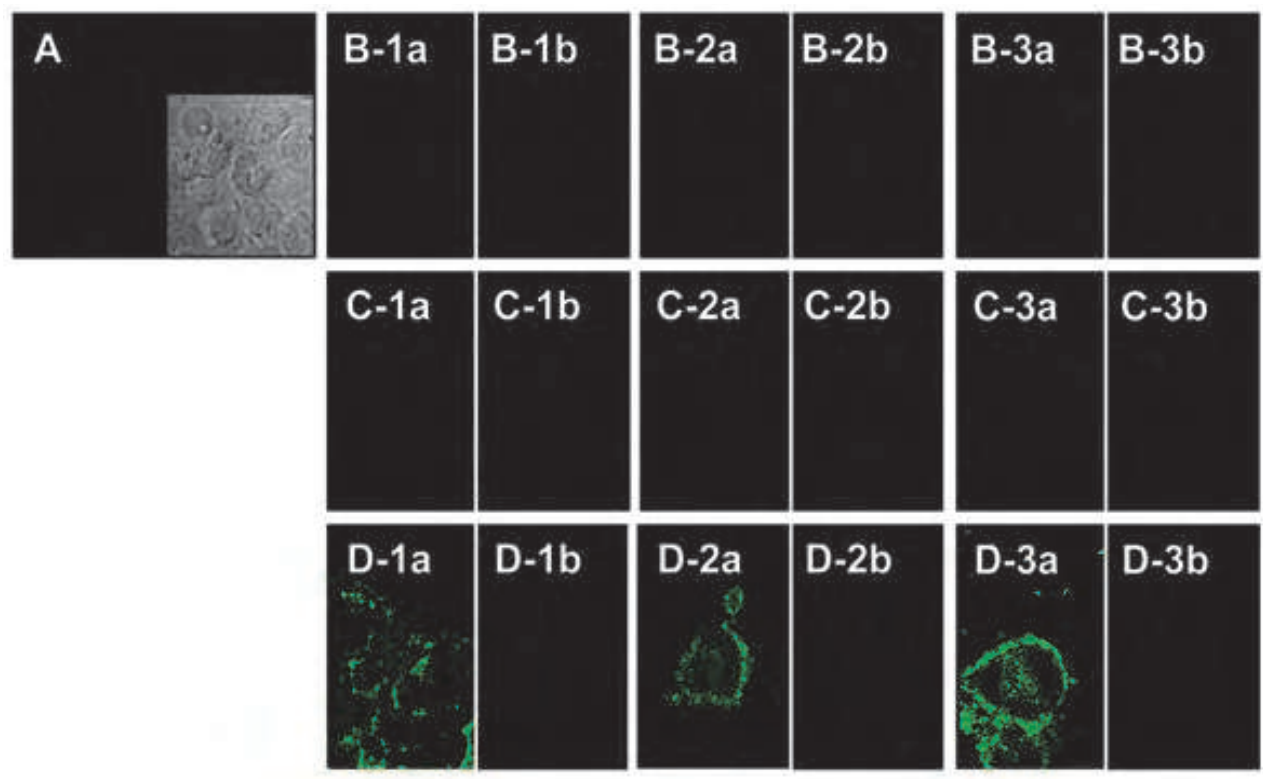

Fig. 4. Efficiency of transfection depends on the kinds of but independent on the concentration of Buforin 2 and pEP-1-EGFPs.

CPP-EGFPs were administered at various concentrations $(1 ; 5 \mu \mathrm{g} / \mathrm{ml}, 2 ; 50 \mu \mathrm{g} / \mathrm{ml} ; 3 ; 500$ $\mu \mathrm{g} / \mathrm{ml}$ ) and observed after $12 \mathrm{hr}$. Vehicle (A), EGFP (B) and EGFP (B-b), Buforin 2-EGFP (C), pEP-1-EGFP (D) was administered to R1 mES cells and detected using confocal microscopy. -a means the $\mathrm{N}$ terminal 6xHis-tag and -b means the $\mathrm{C}$ terminal 6xHis-Tag.

peptide) is an amphipathic helical peptide with a +5 net charge (Hällbrink et al., 2001). A positive charge as well as helicity and amphipathicity are all required for efficient translocation (Wolf et al., 2006). K-FGF and yPFY have no net positive charge. In our laboratory, pET-20b(+)deXhoI modified of pET-20b was used to construct CPP-EGFPs. To get the recombinant CPP-EGFPs, BL21 E. coli were used and purified with $\mathrm{Ni}^{2+}$-affinity column (Qiagen). R1 mES cells were maintained in ES medium containing 1000 IU LIF. R7EGFP-C, MAP-EGFP-C, pVec-EGFP-C, K-FGF-EGFP-C and yPFY-EGFP-C (each $10 \mathrm{ng} / \mathrm{ml}$ ) were incubated with R1 mES cells for $6 \mathrm{hr}$ in ES medium containing 10\% fetal calf serum and then analyzed for translocation with confocal microscope. Propidium iodide was used to stain the nucleus. Interestingly, all of them were localized both to the cytoplasm and karyoplasms (Fig. 5) (Cheon et al., manuscript in preparation). Based on these results, it is suggested that all these carriers can be applied in ES cells.

Recently, it was discovered that R7 mediates the translocation of functional proteins into the cytoplasm of stem cells (Jo et al., 2010). Short-form human ESRRB was cloned in R7-pET$20 \mathrm{~b}(+)$ deXhoI, and recombinant RT-ESRRB was purified in BL21(DE3)pLysS. R7-ESRRB6xHis successfully translocated into the cytoplasm and karyoplasm (Fig. 6), and increased the expression of OCT4, NANOG and SOX2 (Fig. 7). 




Fig. 5. Translocation of CPP-eGFP into R1 ES cells.

(A-F) mES cells were treated with 10ng/ml EGFP (A), R7-EGFP (B), yPFY-EGFP (C), MAPEGFP (D), K-FGF-EGFP (E), or pVec-EGFP (F) for $6 \mathrm{hr}$ at $37^{\circ} \mathrm{C}$. After treatment, all cells were stained with propidium iodide. 1 is eGFP images and 2 is the merged images.



Fig. 6. R7-hESRRB-His6 protein can penetrate the plasma membrane within $5 \mathrm{hr}$ after treatment and are completely localized in the nucleus within $24 \mathrm{hr}$ after treatment. (A-C) the cells were not treated with R7-hESRRB-His6 protein but were immunostained 
with anti-His-Taq(6X) antibody; (D-F) the cells were immunostained with anti-His-Taq(6X) antibody 5 hours after treatment with R7-hESRRB-His6 protein; (G-I) the cells were immunostained with anti-His-Taq(6X) antibody 24 hours after treatment with R7-hESRRBHis6 protein. Images were captured using a confocal microscope (Carl Zeiss LSM 510 META, Zeiss, Jena, Germany) at ×1,000 magnification.

A

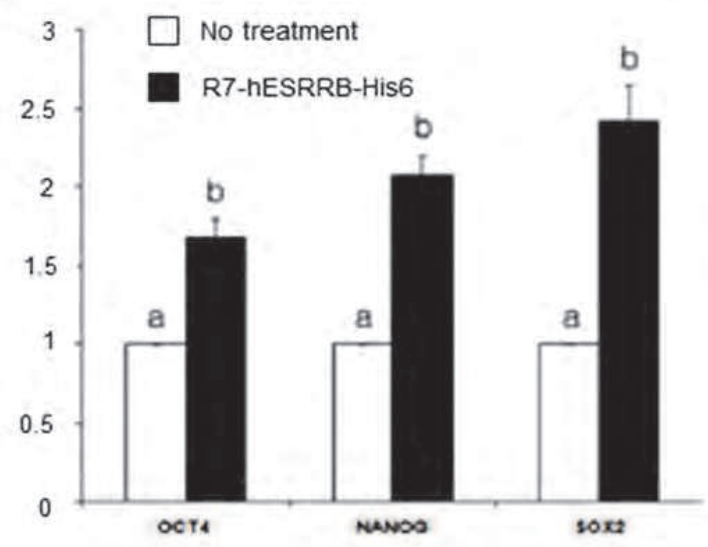

B

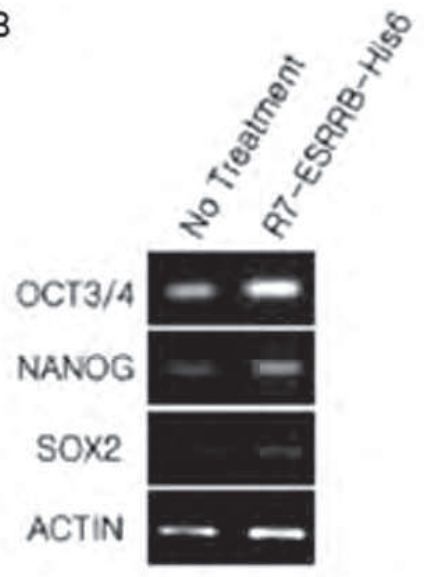

Fig. 7. Treatment with R7-hESRRB-His6 protein for 8 days (192 hr) increases the expression of OCT4, NANOG and SOX2.

A, real-time PCR for the expression of OCT4, NANOG and SOX2; B, agarose gel electrophoresis and EtBr staining after real-time PCR. Statistically significant differences between each group are denoted by different letters $(\mathrm{P}<0.05)$

\subsection{Usage of nanobeads as carriers of functional proteins}

The amount of translocated functional protein is also an important factor in directing the induction of ES cells into specific cell types or maintaining ES cell stemness. In addition, the stability of the CPP-proteins is limited under physiological conditions. The translocation of CPP-proteins into cytoplasm can be inhibited by serum (Furuhata et al., 2006). Therefore, to control ES cell differentiation, it is necessary to regulate the amount of translocated functional protein. To prolong the lifespan of CPPs or CPP-conjugates, they have been modified but this approach has limits (Grunwald et al., 2009).

Recently, nanoparticle techniques have been applied to medicine. Due to the physical and chemical characteristics of nanoparticles, they are more effective at targeting difficult-to-reach sites and have a better side effect profile. Hence, smaller doses of nanomedicines are needed to achieve the same therapeutic effect (Hock et al., 2011; Kuai et al., 2010; Neundorf, 2008). These advantages of nanoparticles as carriers are also evident in the study of ES cells. Poly( $\beta$-amino esters) can fulfill the role of translocation mediator of a VEGF plasmid into hES cells (Yang et al. 2009). A chimeric protein, GFP-FRATtide, attached to a hydrophobically modified 15-nm silica nanoparticle is efficiently delivered to the cytosol of human embryonic kidney cells and rat neural stem cells (Shah et al., 2011). Tran and colleagues studied the effects of nanoparticles on morphological differentiation in mES cells (Tran et al., 2007). However, so far, the efficiency of this technique is not high in ES cell studies. 
Another strategy to use nanoparticles is to apply the metabolic characteristics of ES cells and the characteristics of membranes to the nanoparticles. ES cells can use glucose and require glucose for further development. During the development of preimplantation embryos, the mammalian embryo needs a constant supply of energy substrates to remain viable. Usually, mammalian oocytes receive substrates, especially energy substrates, from the oviduct and uterus because they do not store much substrate in the cytoplasm during oogenesis. Glucose, lactate and pyruvate are essential components in preimplantation embryo culture media, and there are stage-specific preferences for them. Glucose may permit the expression of metabolic enzymes and transporters in compacting morula that are capable of generating the energy required for blastocyst formation. In addition, metabolites of glucose may be involved in cellular activity during the development of preimplantation embryos. Periimplantation embryos need glucose (Biggers and Summers, 2008). Therefore, ES cells can take up glucose as well as glycated proteins. Glucose-coated polymeric nanobeads have been prepared by dispersion polymerization (Jung et al., 2009). As a model protein, enhanced green fluorescent protein was ligated to the nanobeads and successfully translocated into mES cells (Fig. 8, Fig. 9). It is suggested that glucose-coated nanobeads could be a general cargo for the intracellular delivery of various macromolecules in ES cells.


B



Fig. 8. Translocation experiments of the EGFP-ligated beads into R1 mouse embryonic stem cells.

A, the confocal microscopic images. 1-a and 1-b, cells treated with EGFP alone; 2-a and 2-b, cells treated with non-coated beads; $3-a$ and 3-b, cells treated with 5\%-glucose-coated beads; 4-d and 4-m, cells treated with 10\%-glucose-coated beads; $1-\mathrm{a}, 2-\mathrm{a}, 3-\mathrm{a}$, and 4-a are dark field images; 1-b, 2-b, 3-b, and 4-b are merged images (dark-bright fields). The merged images show that the cells are localized at the fluorescent regions. $\mathrm{B}$, the relative intensities of the translocated EGFP. The intensities were measured using confocal microscopy (average \pm SD; the measurements were repeated seven times and averaged). 




Fig. 9. TEM photomicrograph of EGFP-ligated glucose beads in R1 mouse embryonic stem cells. Arrows indicate the translocated beads.

In addition, these nanobeads could be more stable in the blood stream and tissue fluids compared than CPPs. On the other hand, if we add more functions in nanobeads, it can be carry a designed amount of functional protein. For example, shuttle signaling and self degradation can be helpful. To apply glucose nanobeads to in vitro and in vivo systems, further studies are needed, such as optimizing their homing and controlling the transporting amounts in karyoplasms and cytoplasm.

\section{Summary}

ES cells have been used to study the differentiation of various cell types and tissues in vitro, such as neural cells, hematopoietic lineages, cardiomyocytes, hepatocytes, $\beta$-cells, and epithelium. In addition, ES-derived cells have been successfully transplanted into fetal and adult mice, where they have demonstrated morphological and functional integration (Kennedy et al., 1997). However, their use is still in the beginning stages in humans. It is difficult to translate laboratory advancements to human therapy because there are many obstacles to using ES cells in medicine (Piscaglia et al., 2010; Rossi et al., 2010). DNA construct mediated induction of ES cell-differentiation can cause unexpected side effects in the body. Therefore the best way is to use the functional proteins which regulate cellular characteristics such as transcription factors. Those factors can express their functional role, when they are located in proper sites, cytoplasm or karyoplasms. CPPs can be transported into cytoplasm and karyoplasms.

This means that a membrane penetrating carrier is needed for the protein-application to get a specific cell type from ES cells. Based on this, CPP may be a clue to get such a goal. A nanobead which can easily translocate the cell membrane is also a clue to achieve such a goal. Although to apply the CPPs or specific nanoparticle-cargo in cell therapy using 
protein, further studies are needed. These studies would open up new methods of therapy which are safe and economic. However, research on all aspects of ES cell biology will soon overcome these obstacles and make their use in therapy more safe and effective.

\section{References}

Allin EP. 1984. Induction of differentiation in mouse embryonal carcinoma cell lines by coculture with rat glioma cells. Cell Mol Biol 30:377-384.

Amano M, Yamaguchi M, Takegawa Y, Yamashita T, Terashima M, Furukawa J, Miura Y, Shinohara Y, Iwasaki N, Minami A, Nishimura S. 2010. Threshold in state-specific embryonic glycotypes uncovered y a full portrait of dynamic N-glycan expression during cell differentiation. Mol Cell Proteomics 9:523-537.

Andrews PW. 1987. Human teratocarcinoma stem cells: glycolipid antigen expression and modulation during differentiation. J Cell Biochem 35:321-332.

Andrews PW, Banting G, Damjanov I, Arnaud D, Avner P. 1984. Three nonoclonal antibodies defining distinct differentiation antigens associated with different high molecular weight polypeptides on the surface of human embryonal carcinoma cells. Hybridoma 3:347-361.

Armaleo D, Ye GN, Kein TM, Shark KB, Sanford JC, Johnston SA. 1990. Biolistic nuclear transformation of Saccharomyces cerevisiae and other fungi. Curr Genet 17:97-103.

Artavanis-Tsakonas S, Rand Md, Lake RJ. 1999. Notch signaling: Cell fate control and signal intergration in development .Science 284:770-776.

Azizi H, Mehrjardi NZ, Shahbazi E, Hemmesi K, Bahmani MK, Baharvand H. 2010. Dehydroepiandrosterone stimulates neurogenesis in mouse embryonal carcinoma cell- and human embryonic stem cell-derived neural progenitors and induces dopaminergic neurons. Stem Cells Dev 19:809-818.

Balayssac S, Burlina F, Convert O, Bolbach G, Chassaing G, Lequin O. 2006. Comparison of penetratin and other homeodomain-derived cell-penetration peptides: interaction in a membrane-mimicking environment and cellular uptake efficiency. Biochemistry 45:1408-1420.

Bell SM, Aspinall R, Stern PL. 1984. Enrichment of rat NK cytotoxicity for H2-negative murine embryonal carcinoma cells by panning and short-term culture in TCGF. 53:23-32.

Belting M, Dorrell MI, Sandgren S, Aguilar E, Ahamed J, dorfleutner A, Carmeliet P, Mueller BM, Friedlander M, Ruf W. 2004. Regulation of angiogenesis by tissue factor cytoplasmic domain signaling. Nat med 10:502-509.

Berkner KL. 1988. Development of adenovirus vectors for the expression of heterologous genes. Biotechniques 6:616-629.

Biggers ID, Summers MC. 2008. Choosing a culture medium: making informed choices. Fertil Steril 90:473-483.

Boulikas T. 1994. Putative nuclear localization signals (NLS) in protein transcription factors. J Cell Biochem 55:32-58.

Boussif O, Lezoualch F, Zanta MA, Mergny MD, Scherman D, Demeneix B Behr JP. 1995. A versatile vector for gene and oligonucleotide transfer into cells in culture and in vivo: polyethylenimine. Proc Natl Acad Sci U S A 92:7297-7301. 
Bradley A, Evans M, Kaufman MH, Rovertson E. 1984. Formation of germ-line chimaeras from embryo-derived teratocarcinoma cell lines. Nature 309:255-256.

Cao F, Xie X, Gollan T, Zhao L, Narsinh K, Lee RJ, Wu JC. 2010. Comparison of gene-transfer efficiency in human embryonic stem cells. Mol Imaging Bio 12:15-24.

Carvajal-Vergara X, Sevilla A, D'Souza SL, Ang YS, Schaniel C, Lee DF, Yang L, Kaplan AD, Adler ED, Rozov R, Ge Y, Cohen N, Edelmann LJ, Chang B, Waghray A, Su J, Pardo S, Lichtenbelt KD, Tartaglia M, Gelb BE, Lemischka IR. 2010. Patient-specific induced pluripotent stem-cell-derived models of LEOPARD syndrome. Nature 465:808-812.

Chambers I, Smith A. 2004. Self-renewal of teratocarcinoma and embryonic stem cells. Oncogene 23:7150-7160.

Chen QR, Zhang 1, Stass A, Mixson AJ. 2001. Branched co-polymers of histone and lysine are efficient carriers of plasmids. Nucleic Acids Res 29:1334-1340.

Chou TH, Biswas S, Lu S. 2004. Gene delivry using physical methods; an overview. Methods Mol Biol 245:147-166.

Christophersen NS, Helin K. 2010. Epigenetic control of embryonic stem cell fate. J Exp Med 207:2287-2295.

Chugh A, Eudes F, Shim YS. 2010. Cell-penetrating peptides: nanocarrier for macromolecule delivery in living cells. IUBMB Life 62:183-193.

Couto LB, High KA. 2010. Viral vector-mediated RNA interference. Curr Opin Pharmacol . 10:534-542.

Davis HL, Whalen RG, Demeneix BA. 1993. Direct gene transfer into skeletal muscle in vivo; factors affecting efficiency of transfer and stability of experession. Hum Gene Ther 4:151-159.

Delhaise F, Bralion V, Schuurbiers N, Dessy F. 1996. Establishment of an embryonic stem cell line from 8-cell stage mouse embryos. Eur J Morphol 34:237-243.

Dietz GP. 2010. Cell-penetrating peptide technology to deliver chaperones and associated factors in diseases and basic research. Curr Pharm Biotechnol 11:167-174.

Dietz GPH, Bähr M. 2005. Peptideenhanced cellular internalization of proteins in neuroscience. Brain Res Bull 68:103-114.

Doetschman TC, Eistetter H, Katz M, Schmidt W, Kemler R. 1985. The in vitro development of blastocyst-derived embryonic stem cell lines: formation of visceral yolk sac, blood islands and myocardium. J Embryol Exp Morpho 87:27-45.

Doetschman T, Gregg RG, Maeda N, Hooper ML, Melton DW, Thompson S, Smithies O. 1987. Targeted correction of a mutant HPRT gene in mouse embryonic stem cells. Nature 330:576-578.

Dunlap DD, Maggi A, Soria MR, Monaco L. 1997. Nanoscopic structure of DNA condensed for gene delivery, Nucleic Acids Res 25:3095-3101.

Dyson PJ, Poirier F, Watson RJ. 1989. Expression of c-myb in embryonal carcinoma cells and embryonal stem cells. Differentiation 42:24-27.

Edwards MK, Harris JF, McBurney MW. 1983. Induced muscle differentiation in an embryonal carcinoma cell line. Mol Cell Biol 3:2280-2286.

Elmquist A, Hansen M, Langel U. 2006. Structure-activity relationship study of the cellpenetrating peptide pVEC. Biochem Biophys Acta 1758:721-729. 
Elmquist A, Lindgren M, Bartfai T, Langel U. 2010. VE-cadherin derived cell-penetrating peptide, pVEC, with carrier functions. Exp Cell Res 269:237-244.

Evans MJ, Kaufman MH. 1981. Establishment in culture of pluripotential cells from mouse embryos. Nature 292:154-156.

Felgner PL, Gadek TR, Holm M, roman R, Chan HW, Wenz M, Northrop JP, Ringold GM, Danilsen M. 1987. Lipofection: a highly efficient, lipid-meidated DNA-transfection procedure. Proc Natl Acad Sci U S A 84:7413-7417.

Fernanez-Tresquerres B, Canon S, Rayon T, Parnaute B, Crespo M, Torroja C, Manzanares M. 2010. Evolution of the mammalian embryonic pluripotency gene regulatory network. Proc Natl Acad Sci USA 107:19955-19960.

Freiberg RA, Spencer DM, Choate KA, Peng PD, Schreiber SL, Crabtree GR, Khavari PA. 1996. Specific triggering of the Fas signal transduction pathway in normal human keratinocytes. J Biol Chem 271:31666-31669.

Furuhata M, Kawakami H, Toma K, Hattori Y, Maitani Y. 2006. Intracellular delivery of proteins in complexes with oligoarginine-modified liposomes and the effect of oligoarginine length. Bioconjug Chem 17:935-942.

Gautsch JW. 1982. Lack of retrovirus gene expression in teratocarcinoma stem cells is limited to nucleus. Somatic Cell Genet 8:143-149.

Gearhart J. 1998. New potential for human embryonic stem cells. Science 282:1061-1062.

Grabel LB. 1984. Isolation of a putative cell adhesion mediating lectin from teratocarcinoma stem cells and its possible role in differentiation. Cell Differ 15:121-124.

Graham FL, van der Eb AJ. 1973. Transformation of rat cells by DNA of human adenovirus 5. Virology 54:536-539.

Grunwald J, Rejtar T, Sawant R, Wang Z, Torchilin VP. 2009. TAT peptide and its conjugates: proteolytic stability. Bioconjugate Chem 20:1531-1537.

Hällbrink M, Floren A, Elmquist A, Pooga M, Bartfai T, Langel U. 2001. Cargo delivery kinetics of cell-penetrating peptides. Biochim Biophys Acta 1515:101-109.

Hamatani T, Carter MG, Sharov AA, Ko MS. 2004. Dynamics of global gene expression changes during mouse preimplantation development. Dev Cell 6:117-131.

Hassoun R, Puschel B, Viebahn C. 2010. Sox17 expression patterns during gatrulation and early neurulation in the rabbit suggest two sources of endoderm formation. Cells Tissues Organs 191:68-83.

Haupt S, Edenhofer F, Peitz M, Leinhaas A, Brustle O. 2007. Stage specific conditional mutagenesis in mouse embryonic stem cell-derived neural cells and post-mitotic neurons by direct delivery of biologically active Cre recombinase. Stem Cells 25:181-188.

Heath JK, Smith AG. 1988. Regulatory fators of embryonic stem cells. J Cell Sci Suppl 10:257266.

Heng BC, Haider HKh, Sim EK, Cao T, Ng SC. 2004. Strategies for directing the differentiation of stem cells into the cardiomyogenic lineage in vitro. Cardiovasc Res 62:34-42.

Henkel T, Zael U, van Zee K, Müller JM, Fanning E, Baeuerle PA. 1992. Intramolecular masking of the nuclear location signal and dimerization domain in the precursor for the p50 NF-kappa B subunit. Cell 68:1121-1133. 
Henriques ST, Quimtas A, Bagatolli LA, Homblé F, Castanho MA. 2007. Energyindependent translocation of cell-penetrating peptides occurs without formation of pores. A biophysical study with pep-1. Mol Membr Biol 24:282-293.

Hock SC, Ying YM, Wah CL. 2011. A review of the current scientific and regulatory status of nanomedicines and the challenges ahead. DPA J Pharm Sci Technol 65:177-195.

Hong Y, Chen S, Gui J, Schartl M. 2004. Retention of the developmental pluripotency in medaka embryonic stem cells after gene transfer and long-term drug selection for gene tarteting in fish. Transgenic Res 13:41-50.

Hooper MI, Hardy K, Handyside A, Hunter S, Monk M. 1987. HPRT-deficient (LeschNyhan) mouse embryos derived from germ-line colonization by cultured cells. Nature 326:292-294.

Ishizaka S, Shiroi A, KandaS, Yoshikawa M, Tsujinoue H, Kuriyama S, hasuma T, Nakatani K, Takahashi K. 2002. Development of hepatocytes from ES cells after transfection with the HNF-3beta gene. FASEB J 16:1444-1446.

Jakob H. 1984. Stem cells and embryo-derived cell lines: tools for study of gene expression. Cell Differ 15:77-80.

Jemmerson R, Shah N, Takeya M, Fishman WH. 1985. Characterization of the placental alkaline phosphatase-like (Nagao) isozyme on the surface of A431 human epidermoid carcinoma cells. Cancer Res 45:282.287.

Jeong Y, Mangelsdorf DJ. 2009. Nuclear receptor regulation of stemness and stem cell differentiation. Exp Mol Med 41:525-537.

Jo J, Lee Y, Oh MH, Ko JJ, Cheon YP, Lee DR. 2010. Up-regulation of pluripotency-related genes in human amniotic fluid-derived stem cells by ESRB conjugated with cellpenetrating peptide. Dev Reprod 14:243-251.

Johnson MH, McConnell JM. 2004. Lineage allocation and cell polarity during mouse embryogenesis. Semin Cell Dev Biol 15:583-597.

Jones-Villeneuve EM, Rudnicki MA, Harris JF, McBurney MW. 1983. Retinoic acid-induced neural differentiation of embryonal carcinoma cells. Mol Cell Biol 3:2271-2279.

Jung S, Huh S, Cheon YP, Park S. 2009. Intracellular protein delivery by glucose-coated polymeric beads. Chem Commun 33:5003-5005.

Jung S, Park S, Lim H, Cheon Y. 2007. Mouse embryonic stem cell uptakes of Buforin 2 and pEP-1 conjugated with EGFP. Dev Reprod 11:111-119.

Kaufman MH, Robertson EJ, Handyside AH, Evans MJ. 1983. Establishment of pluripotential cell lines from haploid mouse embryos. J Embryol Exp Morphol 73:249-261.

Kennedy M, Firpo M, Choi K, Wall C, Robertson S, Kabrun N, Keller G. 1997. A common precursor for primitive erythropoiesis and definitive haematopoiesis. Nature 386:488-493.

Kim D, Kim CH, Moon JI, Chung YG, Chang MY, Han BS, Ko S, Yang E, Cha KY, Lanza R, Kim KS. 2009. Generation of human induced pluripotent stem cells by direct delivery of reprogramming proteins. Cell Stem Cell 4:472-476.

Kopp JL, Ormsbe BD, Desler M, Rizzino A. 2008. Small increases in the level of sox2 trigger the differentiation of mouse embryonic stem cells. Stem Cells 26:903-911. 
Kuai R, Yuan W, Qin Y, Chen H, Tang J, Yuan M, Zhang Z, He Q. 2010. Efficient delivery of payload into tumor cells in a controlled manner by TAT and thiolytic cleavage PEG co-modified liposomes. Mol Pharm [Epub ahead of print].

Kuehn M, Bradley A, Rovertson EJ, Evans MJ. 1987. A potential animal model for LeschNyhan syndrome through the introduction of HPTR mutations in mice. Nature 326:295-298.

Kumar N, Pethe P, Bhartiya D. 2010. Role of TGFbeta and myofibroblasts in supporting the propagation of human embryonic stem cells in vitro. Hnt J Dev Biol 54:1329-1336.

Kwon SJ, Han K, Jung S, Lee JE Park S, Cheon YP, Lim HJ. 2009. Transduction of the MPGtagged fusion protein into mammalian cells and oocytes depends on amiloridesensitive endocytic pathway. BMC Biotechnol 9:73.

Lehtonen E, Laasonen A, Tienari J. 1989. Teratocarcinoma stem cells as a model for differentiation in the mouse embryo. Int J Dev Biol 33:105-115.

Lin YZ, Yao SY, Veach RA, Torgerson TR, Hawiger J. 1995. Inhibition of nuclear translocation of transcription factor NF-kB by a synthetic peptide containing a cell membrane-permeable motif and nuclear localization sequence. J Biol Chem 270:14255-14258.

Liou JY, Ko BS, Chang TC. 2010. An efficient transfection method for mouse embryonic stem cells. Methods Mol Biol 650:145-153.

Little SR, Lynn DM, Ge Q, Anderson DG, Puram SW, Chen J, Eisen HN, Langer R. 2004. Poly-beta amino ester-containing microparticles enhance the activity of nonviral genetic vaccines. Proc natl Acad Sci U S A 101:9534-9539.

Liu H, Kim Y, Sharkis S, Marchionni L, Jang YY. 2011. In vivo liver regeneration potential of human induced pluripotent stem cells from diverse origins. Sci Transl Med 3:82ra39.

Lu M, Kardel MD, O'Connor MD, Eaves CJ. 2009. Enhanced generation of hematopoietic cells from human hepatocarcinoma cell-stimulated human embryonic and induced pluripotent stem cells. Exp Hematol 37:924-936.

Luxardi G, Marchal L, Thome V, Kodjabachian L. 2010. Distinct Xenopus Nodal ligands sequentially induce mesendoderm and contro gastrulation movements in parallel to the Wnt/PCP pathway. Development 137:417-426.

Ma H, Liu Q, Diamond SL, Pierce EA. 2004. Mouse embryonic stem cells efficiently lipofacted with nuclear localization peptide result in a high yield of chimeric mice and retain germline transmission potency. Methods 33:113-120.

Martin GR. 1981. Isolation of a pluripotent cell line from early mouse embryos culturedin medium conditioned by teratocarcinoma stem cells. Proc Natl Acad Sci U S A 78:7634-7638.

Marucci G, Lammi C, Buccioni M, Dal Ben D, lambertucci C, Amantini C, Santoni G, kandhavelu M, Abbracchio MP, Lecca D, volpini R, Cristalli G. 2011. Comparison and optimization of transient transfection methods at human astrocytoma cell line 1321N1. Anal Biochem 414:300-302.

Matsuoka H, Shimoda S, Ozaki M, Mizukami H, Shibusawa M, Yamada Y, Saito M. 2007. Semi-quantitative expression and knockdown of a target gene in single-cell mouse 
embryonic stem cells by high performance microinjection. Biotechnol Lett 29:341350.

Meissner A, Wernig M, Jaenisch R. 2007. Direct reprogramming of genetically unmodified fibroblasts into pluripotent stem cells. Nat Biotechnol 25:1177-1181.

Moore JC, Atze K, yeung PL, Toro-Ramos Aj, Camarillo C, Thompson K, Ricupero CL, Brenneman MA, Cohen RI, Hart RP. 2010. Efficient, high-throughput transfection of human embryonic stem cells. Stem Cell Res Ther 1:23.

Mummery CL, van den Brink CE, van der Saag PT, de Laat SW. 1984. The cell cycle, cell death, and cell morphology during retinoic acid-induced differentiation of embryonal carcinoma cells. Dev Biol 104:297-307.

Muramatsu H, Muramatsu T. 1983. A fucosyltransferase in teratocarcinoma stem cells. Decreased activity accompanying differentiation to parietal endoderm cells. FEBS Lett 163:181-184.

Murthy N, Xu M, Schuck S, Kunisawa J, Shastri N, Frehet Mj. 2003. A macromolecular delivery vehicle for protein-based vaccines; acid-degradable protein-loaded microgels. Proc Natl Acad Sci U S A 100:4995-5000.

Navarro P, Oldfield A, Legoupi J, Festuccia N, Dubois A, Attia M, Schoorlemmer J, Rougeulle C, Chambers I, Avner P. 2010. Molecular coupling of Tsix regulation and pluripotency. Nature 468:457-460.

Neundorf I, Rennert R, Franke J, Közle I, Bergmann R. 2008. Detailed analysis concerning the biodistribution and metabolism of human calcitonin-derived cell-penetrating peptides. Bioconjug Chem 19:1596-1603.

Nichols J, Smith A. 2011. The origin and identity of embryonic stem cells. Development 138:3-8.

Nilsson IM, Gafvelin G, von Heijne G. 1993. Different sec-requirements for signal peptide cleavage and protein translocation in a model E. coli protein. FEBS Lett 318:7-10.

Osakada F, Takahashi M. 2011. Neural induction and patterning in mammalian pluripotent stem cells. CNS neurol Disord Drug Targets 10:419-432.

Pagano JS, Vaheri A. 1965. Enhancement of infectivity of poliovirus RNA with diethylaminoethyl-dextran (DEAE-D). Arch Gesamte Virusforsch 17:456-464.

Park CH, Lee SH. 2007. Efficient generation of dopamine neurons from human embryonic stem cells. Methods Mol Biol 407:311-322.

Park CB, Yi KS, Matsuzaki K, Kim MS, Kim SC. 2000. Structure-activity analysis of buforin 2, a histone H2A-derived antimicrobial peptide: the proline hinge is responsible for the cell-penetrating ability of buforin 2. Proc Natl Acad Sci U S A 97:8245-8250.

Park IH, Zhao R, West JA, Yabuuchi A, Huo H, Ince TA, Lerou PH, Lensch MW, Daley GQ. 2008. Reprogramming of human somatic cells to pluripotency with defined factors. Nature 451:141-146.

Petrescu AD, Vespa A, Huang H, Mclntosh AL, Schroeder F, Kier AB. 2009. Fluorescent sterols monitor cell penetrating peptide Pep-1 mediated uptake and intracellular targeting of cargo protein in living cells. Biochem Biophys Acta 1788:425-441.

Piscaglia AC, Campanale M, Gasbarrini A, Gasbarrini G. 2010. Stem cell-based therapies for liver diseases: state of the art and new perspectives. Stem Cells 2010:259461. 
Pooga M, Hällbrink M, Zorko M, Laggel U. 1998. Cell penetration by transportan. FASEB J 12:67-77.

Pooga M, Langel U. 2005. Synthesis of cell-penetrating peptides for cargo delivery. 298:7789.

Redshaw Z, Strain AJ. 2010. Human haematopoietic stem cells express Oct4 pseudogenes and lack the ability to initiate Oct4 promoter-driven gene expression. J Negat Results Biomed 9:2.

Risau W, Sariola H, Zerwes HG, Sasse J, Ekblom P, Kemler R, Doetschman T. 1988. Vasculogenesis and angiogenesis in embryonic-stem-cell-derived embryoid bodies. Development 102:471-478.

Robbins PD, Ghivizzani SC. 1998. Viral vectors for gene therapy. Pharmacol Ther 80:35-47.

Rocha PP, Scholze M, Bleiss W, Schrewe H. 2010. Med12 is essential for early mouse development and for canonical Wnt and Wnt/PCP signaling. Development 137:2723-2731.

Rosenstraus MJ, Sterman B, Carr A, Brand L. 1984. Fibroblast feeder layers inhibit differentiation of retinoic acid-treated embryonal carcinoma cells by increasing the probability of stem cell renewal. Exp Cell Res 152:378-389.

Rossant J, Papaioannou VE. 1984. The relationship between embryonic, embryonal carcinoma and embryo-derived stem cells. Cell Differ 15:155-161.

Rossi SL, Nistor G, Wyatt T, Yin H, Poole AJ, Weiss JH, Gardener MJ, Dijkstra S, Fischer DF, Keirstead HS. 2010. Histological and functional benefit following transplantation of motor neuron progenitors to the injured rat spinal cord. PLoS One 5:e11852.

Ruch JV. 1967. Effect of dexamethasone phosphate on the differentiation of embryonic stem bronchi in vivo and in vitro. CR Seances Soc Bio Fil 161:1339-13342.

Sawant R, Torchilin V. 2010. Intracellular transduction using cell-penetrating peptides. Mol biosyst 6:628-640.

Saxena AK, Singh D, Gupta J. 2010. Role of stem cell research in therapeutic purpose-a hope for new horizon in medical biotechnology. J Exp Ther Oncol 8:223-233.

Schindler J, Sherman MI. 1984. Changes in protein synthetic profiles during retinoic-acid induction of differentiation of murine embryonal carcinoma cells. 28:78-85.

Schwartzberg PL, Goff SP, Robertson EJ. 1989. Germ line transmission of a c-abl mutation produced by targeted gene disruption in ES cells. Science 246:799-803.

Scott RW, Vogt TF, Croke ME, Tilghman SM. 1984. Tissue-specific activation of a cloned alpha-fetoprotein gene during differentiation of a transfected embryonal carcinoma cell line. Nature 310:562-567.

Sekiya S, Kawata M, Iwasawa H, Inaba N, Sugita M, Suzuki N, Motoyama T, Yamamoto T, Takamizawa H. 1985. Characterization of human embryonal carcinoma cell lines derived from testicular germ-cell tumors. Differentiation 29:259-267.

Shah DA, Kwon SJ, Bale SS, Banerjee A, Dordick JS, Kane RS. 2011. Regulation of stem cell signaling by nanoparticle-meidated intracellular protein delivery. Biomaterials 32:3210-3219.

Shimotohno K, Temin HM. 1981. Formation of infectious progeny virus after insertion of hepes simplex thymidine kinase gene into DNA of an avian retro virus. Cell 26:6777. 
Silvan U, Diez-Torre A, Arluzea J, Andrade R, Silio M, Arechaga J. 2009. Hypoxia and pluripotency in embryonic and embryonal carcinoma stem cell biology. Differentiation 2009 78:159-168.

Smith AG, Heath JK, Donaldson DD, Wong GG, Moreau J, Stahl M, Rogers D. 1988. Inhibition of pluripotential embryonic stem cell differentiation by purified polypeptides. Nature 336:688-690.

Smolich BD, Papkoff J. 1994. Regulated expression of Wnt family members during neuroectodermal differentiation of P19 embryonal carcinoma cells: overexpression of Wnt-1 perturbs normal differentiation-specific properties. Dev Biol 166:300-310.

Spence JR, Mayhew CN, Rankin SA, Kuhar MF, Vallance JE Tolle K, Hoskins EE, Kalinichenko W, Wells SI, Zorn AM, Shroyer NF, Wells JM. 2011. Directed differentiation of human pluripotent stem cells into intestinal tissue in vitro. Nature 470:105-109.

Strelchenko N, Verlinsky O, Kukharenko V, Vrlinsky Y. 2004. Morual-derived human embryonic stem cells. Reprod Biomed Online 9:623-629.

Suda Y, Suzuki M, Ikawa Y, Aizawa S. 1987. Mouse embryonic stem cells exhibit indefinite proliferative potential. J Cell Physiol 133:197-201.

Svingen T, Wilhelm D, Combes AN, Hosking B, Harley VR, Sinclair AH, Koopman P. 2009. Ex vivo magnetofection: A novel strategy for the study of gene function in mouse organogenesis. Dev Dyn 238:956-964.

Taatjes DJ, Marr MT, Jjian R. 2004. Regulatory diversity among metazoan co-activator complexs. Nat Rev Mol Cell Biol 5:403-410.

Takahashi K, Yamanaka S. 2006. Induction of pluripotent stem cells from mouse embryonic and adult fibroblast cultures by defined factors. Cell 126:663-676.

Takahashi K, Ohnuki M, Narita M, Ichisaka T, Tomoda K, Yamanaka S. 2007. Strategies and new developments in the generation of patient-specific pluripotent stem cells from adult human fibroblasts by defined factors. Cell 131:861-872.

Takeshima K, Chikushi A, Lee KK, Yonehara S, Matsuzaki K. 2003. Translocation of analogues of the antimicrobial peptides magainin and buforin across human cell membranes. J Biol Chem 278:1310-1315.

Tang MX, Szoka FC. 1997. The influence of polymer structure on the interations of cationic polymers with DNA and morphology of the resulting complexes. Gene Ther 4:823832.

Templeton NS, Lasic DD, Frederik PM, Strey HH, Roberts DD, Pavlakis GN. 1997. Improved DNA: liposome complexes for increased systemic delivery and gene expression. Nat Biotechnol 15:647-652.

Thomson JA, Itskovitz-Eldor J, Shapiro SS, Waknitz MA, Swiergiel JJ, Marshall VS, Jones JM. 1998. Embryonic stem cell lines derived from human blastocysts. Science 282:11451147.

Thomson JA, Kalishman J, Golos TG, Durning M, Harris CP, Becker RA, Hearn JP. 1995. Isolation of a primate embryonic stem cell line. Proc Natle Acad Sci USA 92:78447848 . 
Torchilin VP, Levchenko TS, Rammohan R, Volodina N, Papahadjopoulos-Sternberg B, D'Souza GGM. 2003. Cell transfection in vitro and in vivo with nontoxic TAT peptide-liposome-DNA complexes. Proc Natl Acad Sci U S A 100:1972-1977.

Tran DN, Ota LC, Jacobson JD, Paaton WC, Chang PJ. 2007. Influence of nanoparticles on morphological differentiation of mouse embryonic stem cells. Fertil Steril 87:965970.

Verdurmen WP,. Brock R. 2011. Biological responses towards cationic peptides and drug carriers. Trends Pharmacol Sci 32:116-124.

Villa-Diaz LG, Garcia-Perez JL, Krebsbach PH. 2010. Enhanced transfection efficiency of human embryonic stem cells by the incorporation of DNA liposomes in extracellular matrix. Stem Cells Dev 19:1949-1957.

Wadia JS, Dowdy SF. 2003. Modulation of cellular function by TAT mediated transduction of full length proteins. Curr Protein Pept Sci 4:97-104.

Wang Y, Krushel LA, Edelman GM. 1996. Targeted DNA recombination in vivo using an adenovirus carrying the cre recombinase gene. Proc Natl Acad Sci USA 93:39323936.

Wartiovaara J, Liesi P, Rechardt L. 1984. Expression of laminin and fibronectin in endodermal and neural differentiation of F9 embryonal carcinoma cells. Prog Clin Biol Res 151:233-247.

Wasungu L, Hoekstra D. 2006. Cationic lipids, lipoplexes and intracellular delivery of genes. J Control Release 116:255-264.

Watanabe Y, Horie S, Funaki Y, Kikuchi Y, Yamazaki H, Ishii k, Mori S, Vassaux G, Kodama T. 2010. Delivery of $\mathrm{Na} / \mathrm{I}$ symporter gene into skeletal muscle using nanobubbles and ultrasound: visualization of gene expression by PET. J Nucl Med 51:951-958..

Williams RL, Hilton DJ, Pease S, Willson TA Stewart CL, Gearing DP, Wagner EF, Metcalf D, Nicola NA, Gough NM. 1988. Myeloid leukaemia inhibitory factor maintains the developmental potential of embryonic stem cells. Nature 336:684-687.

Wolf Y, Pritz S, Abes S, Bienert M, Lebleu B, Oehlke J. 2006. Structural requirements for cellular uptake and antisense activity of peptide nucleic acids conjugated with various peptides. Biochemistry 45:14944-14954.

Wolpert L. 1978. Pattern formation in biological development. Sci Am 239:154-164.

Xavier J, Singh S, Dean DA, Rao NM, Gopal . 2009. Designed multi-domain protein as a carrier of nucleic acids into cells. J Control Release 133:154-160.

Xia H, Mao Q, Davidson BL. 2001. The HIV Tat protein transduction domain improves the biodistribution of beta-glucuronidase expressed from ecombinant viral vetors. Nat Biotechnol 19:640-644.

Yamanaka Y, Ralston A, Stephenson RO, Rossant J. 2006. Cell and molecular regulation of the mouse blastocyst. Dev Dyn 235:2301-2314.

Yang F, Green JJ, Dino T, Keung L, Cho SW, Park H, Langer R, Anderson DG. 2009. Gene delivery to human adult and embryonic cell-derived stem cells using biodegradable nanoparticulate polymeric vectors. Gene Ther 16:533-546.

Yang J, Gao C, Chai L, Ma Y. 2010. A novel SALL4/OCT4 transcriptional feedback network for pluripotency of embryonic stem cells. PLoS One 5:e10766. 
Yu J, Vodyanik MA, Smuga-Otto K, Antosiewicz-Bourget J, Frane JL, Tian S, Nie J, Jonsdottir GA, Ruotti V, Stewart R, Slukvin II, Thomson JA. 2007. Induced pluripotent stem cell lines derived from human somatic cells. Science 318:19171920.

Zákány J, Burg K, Raskó I. 1984. Spontaneous differentiation in the colonies of a nullipotent embryonal carcinoma cell line (F9). Differentiation 27:146-151.

Zhang G, Budker V, Wolff JA. 1999. High levels of foreign gene expression in hepatocytes after tail vein injections of naked plasmid DNA. Hum Gene Ther 10:1735-1737.

Zhao X, Yu SB, Wu FL, Mao ZB, Yu CL. 2006. Transfection of primary chondrocytes using chitosan-pEGFP nanoparticles. J Control Release 112:223-228.

Zijlstra M, Li E, Sajjai F, Subramani S, Jaenish R. 1989. Germ-line transmission of a disrupted $\beta 2$-microglobulin gene produced by homologous recombination in embryonic stem cells. Nature 342:435-438. 




\author{
Embryonic Stem Cells - Basic Biology to Bioengineering \\ Edited by Prof. Michael Kallos
}

ISBN 978-953-307-278-4

Hard cover, 478 pages

Publisher InTech

Published online 15, September, 2011

Published in print edition September, 2011

Embryonic stem cells are one of the key building blocks of the emerging multidisciplinary field of regenerative medicine, and discoveries and new technology related to embryonic stem cells are being made at an ever increasing rate. This book provides a snapshot of some of the research occurring across a wide range of areas related to embryonic stem cells, including new methods, tools and technologies; new understandings about the molecular biology and pluripotency of these cells; as well as new uses for and sources of embryonic stem cells. The book will serve as a valuable resource for engineers, scientists, and clinicians as well as students in a wide range of disciplines.

\title{
How to reference
}

In order to correctly reference this scholarly work, feel free to copy and paste the following:

Yong-Pil Cheon (2011). Embryonic Stem Cells: Introducing Exogenous Regulators into Embryonic Stem Cells, Embryonic Stem Cells - Basic Biology to Bioengineering, Prof. Michael Kallos (Ed.), ISBN: 978-953-307-278-4, InTech, Available from: http://www.intechopen.com/books/embryonic-stem-cells-basic-biology-tobioengineering/embryonic-stem-cells-introducing-exogenous-regulators-into-embryonic-stem-cells

\section{INTECH}

open science | open minds

\section{InTech Europe}

University Campus STeP Ri Slavka Krautzeka 83/A 51000 Rijeka, Croatia Phone: +385 (51) 770447

Fax: +385 (51) 686166 www.intechopen.com

\section{InTech China}

Unit 405, Office Block, Hotel Equatorial Shanghai No.65, Yan An Road (West), Shanghai, 200040, China 中国上海市延安西路65号上海国际贵都大饭店办公楼405单元 Phone: +86-21-62489820

Fax: $+86-21-62489821$ 
(C) 2011 The Author(s). Licensee IntechOpen. This chapter is distributed under the terms of the Creative Commons Attribution-NonCommercialShareAlike-3.0 License, which permits use, distribution and reproduction for non-commercial purposes, provided the original is properly cited and derivative works building on this content are distributed under the same license. 